\title{
Influence of Rootstocks on Plant Volume, Root Growth, Biomass, Water Relations and Leaf Nutrient Status of Almond cv. Non Pareil under Different Soil Moisture Regimes
}

\author{
M.K. Sharma* \\ Department of Pomology, Dr. Y.S. Parmar University of Horticulture and Forestry, \\ Nauni, Solan (H.P.), India \\ *Corresponding author
}

\section{Keywords}

Almond, Bitter almond, Wild peach, Soil moisture tension, Photosynthesis, Stomatal conductance, Leaf nutrient status

Article Info

Accepted: 10 October 2018 Available Online: 10 November 2018

\section{A B S T R A C T}

An experiment was carried out to study the influence of rootstocks on plant volume, root growth, biomass, water relations and leaf nutrient status of almond cv. Non Pareil under different soil moisture regimes at the experimental farm of Department of Pomology, Dr. Y.S. Parmar University of Horticulture and Forestry, Nauni, Solan (H.P.). Almond plants cv. Non Pareil were raised on bitter almond and wild peach rootstocks and were subjected to different soil moisture regimes $(-0.5,-2.5,-5.0$ and -10.0 bar). The experiment was laid out in a factorial Randomized Block Design with three replications. Results obtained revealed that almond plants raised on wild peach rootstock had more plant volume $(0.81$ $\left.\mathrm{m}^{3}\right)$ than on bitter almond rootstock $\left(0.70 \mathrm{~m}^{3}\right)$. Plant volume was highest at less soil moisture stress $(-0.5$ bar) than at higher water stress. Root length and weight was more in plants raised on bitter almond rootstock $(19.64 \mathrm{~m}$ and $67.93 \mathrm{~g})$ than those raised on wild peach rootstock. Length and dry weight of roots was also higher in plants irrigated at -0.5 bar $(22.82 \mathrm{~m}$ and $87.75 \mathrm{~g})$ than those plants irrigated at higher soil moisture stress. Rate of photosynthesis was higher in plants raised on wild peach rootstock $\left(14.48 \mu \mathrm{mol} / \mathrm{m}^{2} / \mathrm{S}\right)$ however stomatal conductance was higher in plants raised on bitter almond rootstock $(0.48$ $\left.\mathrm{mmol} / \mathrm{m}^{2} / \mathrm{S}\right)$. However these two parameters were more in plants maintained at -0.5 bar in comparison to plants maintained at higher soil moisture stresses. Leaf N, P and K contents were not significantly influenced by rootstocks however the contents were high under low soil moisture stress (-0.5 and -2.5 bar). Plants raised on bitter almond rootstock had less reduction in different parameters recorded at high soil moisture stresses (-5.0 and -10.0 bar) than the plants raised on wild peach rootstock thus can tolerate water stress better as compared to wild peach rootstock.

\section{Introduction}

Almond (Prunus amygdalus Batsch.) is one of the most important nut fruit of the world. Because of its stupendous qualities, it has gained a widespread popularity in the world. The importance of almond growing lies in its high nutritive value, non-perishable nature, easy transport, long storage life under natural conditions and high market value. Almond kernel is cherished for its high calorific value, because of high protein and fat contents. Besides, it is endowed with significant amount of vitamins and minerals. In India, its 
cultivation is mainly confined to hilly areas of Jammu and Kashmir, Himachal Pradesh and Uttarakhand. In Himachal Pradesh, cool and dry areas are quite suitable for its cultivation. However, its cultivation is also picking up in mid and low hill regions of the state where it is mainly grown for green almonds. However, it is quite frustating that the productivity of almonds is quite low in India as compared to leading almond producing countries of the world. There could be several reasons for the low productivity in almond, but two of the prominent reasons are inadequate moisture and improper selection of rootstock. In low and mid hill regions, almond is mainly grown under rainfed conditions. The rains, in these areas, are mostly received during winter and monsoon season and even this rainfall is not well distributed. Thus the soil moisture generally remains low during the growth and the development of fruits. The low soil moisture results in low flower bud differentiation, poor fruit set and heavy fruit drop and sometime even causes the death of the tree. It is also a well-established fact that irrigation plays a vital role in cultivation of any crop and almond is no exception. Where natural precipitation is inadequate during the critical periods of growth and fruiting, particularly from leafing out till May, the almond trees are required to be irrigated to get the higher yields of quality nuts. Where water in sufficient amounts, is not available for irrigation, it is desirable to use drought tolerant rootstock. Due to the non-availability of clonal rootstocks in India, almond is mainly propagated on bitter almond, wild peach and behmi rootstocks. In Himachal Pradesh, bitter almond and wild peach are recommended as the rootstocks for almond but their performance under irrigated and drought conditions is not known. Amongst the scion cultivars, Nonpareil has been found to be the most promising and are recommended for cultivation in the state. Rootstock influence vigour, water relations and nutrient status of the fruit trees grafted on to them. The uptake of nutrients is also governed by soil moisture. Water stress conditions reduce the uptake of nutrients which result in poor plant performance. So, the evaluation of rootstocks for their drought tolerance is extremely important.

\section{Materials and Methods}

The study was undertaken at the experimental farm of the Department of Pomology, Dr Y. S. Parmar University of Horticulture and Forestry, Solan (H.P.). The containers of 200 litre capacity, cut into two equal halves, were used for growing plants. The containers (50 $\mathrm{cm}$ in diameter), were filled with $70 \mathrm{~kg}$ soil mixture containing orchard soil, sand and farm yard manure in the ratio of 3: 1:1. One year old Nonpareil almond plants grafted on wild peach and bitter almond rootstocks were planted in the containers. The experiment was laid out in factorial Randomised Block Design with three replications. During the course of study, the plant material was covered with plastic sheet to avoid direct entry of rain water into the containers. Before the commencement of the experiment, soil moisture in all the containers was brought to field capacity. The soil moisture was allowed to deplete to -0.5 , $2.5,-5.0$ and -10.0 bar. As soon as the soil moisture level in containers reached the desired tension, it was brought to field capacity by applying a measured quantity of water. In order to determine the amount of water retained by soil at different soil moisture tensions, the soil moisture characteristic curve was prepared, which served as a guideline to calculate the quantity of water to be applied to bring the soil moisture in the containers to field capacity from $-0.5,-2.5,-5.0$ and -10.0 bar.

Plant volume was worked out with the help of the formula as given by Westwood (1993). Length of primary and secondary roots (upto 2 
$\mathrm{mm}$ in diameter) was determined with the help of measuring tape. Length of tertiary roots and root hairs was recorded on Comair Root Length Scanner. The total root length of plant was expressed in meters. Dry weight of the roots of experimental plants was recorded and expressed in grams. Total dry weight of shoots and roots of plants (biomass) was determined at the end of the experiment and was expressed in grams. Leaf photosynthesis and stomatal conductance were recorded when moisture content of the soil reached the required tension i.e. $-0.5,-2.5,-5.0$ and -10.0 bar. The observations were recorded between 9.00 to $11.00 \mathrm{AM}$ with the help of LlCOR6200 portable photosynthesis meter and the results were expressed in $\mu \mathrm{mol} / \mathrm{m}^{2} / \mathrm{S}$ and $\mathrm{mmol} / \mathrm{m}^{2} / \mathrm{S}$ for photosynthesis and stomatal conductance, respectively.

For the estimation of leaf nutrient status, leaf samples were collected from the middle of current season's' growth as recommended by Kenworthy (1964), during first week of July. Cleaning, drying, grinding and storage of samples were carried out in accordance with the procedure laid by Chapman (1964). Digestion of the samples for the estimation of nitrogen was carried out in concentrated sulphuric acid by adding digestion mixture as described by Jackson (1967). For the estimation of other elements, samples were digested in diacid mixture prepared by mixing nitric acid and perchloric acid in the ratio of 4 : 1 (Piper, 1966).

Total nitrogen was determined by microKjeldahl's method (A.O.A.C., 1980). Total phosphorus was determined by Vanadomolybdo-phosphoric yellow colour method (Koeing and Johnson, 1942). Total K was determined on ECIL Atomic Absorption Spectrophotometer model-4129. The results for these nutrient elements were expressed in percentage on dry weight basis. The data generated from the present investigations were subjected to statistical analysis as per the procedures described by Cochran and Cox (1963).

\section{Results and Discussion}

\section{Plant volume}

Perusal of the data given in Table 1 reveals that plant volume was markedly influenced by both the rootstocks. Plants grafted on wild peach produced the maximum plant volume $\left(0.81 \mathrm{~m}^{3}\right)$ whereas, those on bitter almond rootstock had the lowest volume $\left(0.70 \mathrm{~m}^{3}\right)$. Kumar (1987) also observed that almond varieties on wild peach rootstock were more vigorous than on bitter almond rootstock. Variable influence of rootstock on scion vigour has also been reported in almond by Micke et al., (1996) Soil moisture levels also had a marked effect on the volume of plants. Plants irrigated at -0.5 bar soil moisture tension registered appreciably higher volume $\left(1.32 \mathrm{~m}^{3}\right)$ than those irrigated at other soil moisture levels. The minimum volume $(0.28$ $\mathrm{m}^{3}$ ) was observed in the plants irrigated at 10.0 bar. Interaction between rootstock and moisture level had a marked influence on plant volume. Plants on wild peach rootstock, receiving irrigation at -0.5 bar attained the highest volume $\left(1.47 \mathrm{~m}^{3}\right)$ as compared to other treatments. However, plants on wild peach, receiving irrigation at $-10.0 \mathrm{bar}$, had the lowest volume $\left(0.26 \mathrm{~m}^{3}\right)$. Higher volume of plants irrigated at -0.5 bar, might be due to the fact that at this level the soil moisture was readily available to the plants during the growing season. Present findings are in accordance with those of Neilsen et al., (2014) and Malik et al., (1994).

\section{Total root length}

The perusal of data given in Table 2 reveals that total root length was significantly influenced by the rootstocks. Plants grafted on 
bitter almond rootstock had the highest root length $(19.64 \mathrm{~m})$ whereas, those on wild peach had the lowest root length $(12.11 \mathrm{~m})$. Kester and Grasselly (1987) reported that almond seedling roots were deep with typical root system and had few branches, whereas, peach root system tended to be somewhat shallow rooted with larger number of somewhat smaller roots. Soil moisture levels also had a marked effect on the total root length. Plants irrigated at -0.5 bar soil moisture tension produced appreciably higher root length $(22.82 \mathrm{~m})$ than those irrigated at other soil moisture levels. The lowest root length (10.06 m) was observed in the plants irrigated at 10.0 bar. Interaction between rootstock and moisture level also had a marked influence on the root length. Plants on bitter almond rootstock, irrigated at -0.5 bar, produced the highest root length $(28.64 \mathrm{~m})$. However, plants on wild peach rootstock, receiving irrigation at -10.0 bar, registered the lowest root length $(8.17 \mathrm{~m})$. These findings are in agreement with those of Abrisqueta et al., (1994), who observed that higher soil moisture level resulted in the best developed root system of almond trees. The reduction in root length irrigated at -10.0 bar, could be due to water stress conditions leading to reduction in root growth (Chandel and Chauhan, 1994).

\section{Root weight}

Perusal of data presented in Table 3 shows that the plants on different rootstocks differed in their root weight. Maximum root weight $(67.93 \mathrm{~g})$ was observed in plants on bitter almond rootstock. However, it was minimum $(49.78 \mathrm{~g})$ in plants grafted on wild peach rootstock. The present findings are in agreement with those of Senin et al., (1989) who observed variable effects of rootstock on length and weight of roots. Root weight was also markedly influenced by soil moisture. Maximum root weight $(87.75 \mathrm{~g})$ was recorded in plants which were irrigated at -0.5 bar while it was minimum $(37.76 \mathrm{~g})$ in plants irrigated at -10.0 bar. This might be due to the fact that soil moisture at -0.5 bar was readily available to the plants during growing season which induced better root growth. These findings are in agreement with those of Abrisqueta et al., (1994), who observed that higher soil moisture level resulted in the best developed root system of almond trees. The interaction of rootstock and moisture level was found to be significant in respect of root weight. Appreciably greater root weight (90.99 g) was observed in the plants grafted on bitter almond rootstock and irrigated at -0.5 bar as compared to the other treatments. Lowest root weight $(30.23 \mathrm{~g})$ was recorded in plants on wild peach rootstock and irrigated at -10.0 bar. The plants which received irrigation at -0.5 bar produced significantly more length and weight of roots than those irrigated at $-2.5,-5.0$ and -10.0 bar. The reduction in root weight of plants, irrigated at -10.0 bar, could be due to water stress conditions leading to reduction in root growth (Chandel and Chauhan, 1994).

\section{Biomass (dry weight of roots and shoots)}

Perusal of the data given in Table 4 reveals that rootstock significantly influenced the plant biomass. Plants raised on bitter almond rootstock produced markedly higher biomass $(281.4 \mathrm{~g})$ than those on wild peach rootstock (270.1 g). Plant biomass was also significantly influenced by soil moisture regimes. Plants irrigated at -0.5 bar had the highest biomass (396.6 g) which was appreciably higher than those maintained at other moisture levels. This might be due to the fact that soil moisture at 0.5 bar was readily available to the plants during growing season which induced better root growth. These findings are in agreement with those of Abrisqueta et al., (1994). Minimum biomass $(180.1 \mathrm{~g})$ was recorded in the plants irrigated at -10.0 bar. The interaction of rootstock and moisture level had a marked effect on plant biomass. Appreciably 
higher biomass $(403.0 \mathrm{~g})$ was recorded in the plants on wild peach rootstock and irrigated at -0.5 bar as compare to other rootstock and moisture level combinations. Plants on wild peach rootstock and irrigated at -10.0 bar registered the lowest biomass (166.3 g).

\section{Photosynthesis rate}

It is evident from the data presented in Table 5 that the rate of photosynthesis was not influenced by the rootstocks. However plants raised on wild peach rootstock had higher rate of photosynthesis than on bitter almond rootstock. These observations are in conformity with the findings to Syrbu et al., (1983), who observed higher photosynthesis in Golden Jubilee peach on peach rootstock than on almond, apricot and cherry plum rootstocks. However, the rate of photosynthesis was markedly influenced by irrigation levels. Highest, photosynthesis $\left(19.62 \mu \mathrm{mol} / \mathrm{m}^{2} / \mathrm{S}\right)$ was recorded in the plants irrigated at -0.5 bar while the lowest rate of photosynthesis $\left(8.85 \mu \mathrm{mol} / \mathrm{m}^{2} / \mathrm{S}\right) \quad$ was observed in plants irrigated at -10.0 bar. Interaction between rootstock and moisture level significantly influenced the' rate of photosynthesis. Highest photosynthetic rate $\left(19.82 \mu \mathrm{mol} / \mathrm{m}^{2} / \mathrm{S}\right)$ was recorded in the plants on wild peach rootstock and irrigated at -0.5 bar whereas the lowest rate of photosynthesis $\left(8.51 \mu \mathrm{mol} / \mathrm{m}^{2} / \mathrm{S}\right)$ was observed in plants on the same rootstock but irrigated at -10.0 bar. This could be due to the fact that water stress suppresses photosynthesis by reducing the leaf area, closing of stomata and by checking the activity of dehydrated protoplasmic machinery. The present findings are in conformity with those of Natali et al., (1996).

\section{Stomatal conductance}

It is evident from Table 6 that the values of stomatal conductance differed in plants grown on different rootstocks. Plants on bitter almond rootstock had higher stomatal conductance $\left(0.48 \mathrm{mmol} / \mathrm{m}^{2} / \mathrm{S}\right)$ than those on wild peach rootstock $\left(0.47 \mathrm{mmol} / \mathrm{m}^{2} / \mathrm{S}\right)$, but both were statistically at par with each other. Chandel and Chauhan (1992) who also recorded variable effects of rootstocks on the stomatal conductance. Soil moisture levels also exhibited significant influence on the stomatal conductance. Plants which were irrigated at -0.5 bar had the higher stomatal conductance $\left(0.81 \mathrm{mmol} / \mathrm{m}^{2} / \mathrm{S}\right)$ than those irrigated at $-2.5,-5.0$ and -10.0 bar. The minimum value of stomatal conductance $(0.12$ $\mathrm{mmol} / \mathrm{m}^{2} / \mathrm{S}$ ) was observed in plants irrigated at -10.0 bar. Interaction of rootstock and moisture level had a marked effect on the stomatal conductance of leaves. The plants grafted on bitter almond rootstock had appreciably higher stomatal conductance $(0.83$ $\mathrm{mmol} / \mathrm{m}^{2} / \mathrm{S}$ ) while those on same rootstock but irrigated at -10.0 bar had the lowest stomatal conductance $\left(0.11 \mathrm{mmol} / \mathrm{m}^{2} / \mathrm{S}\right)$. These findings are in conformity with those of Higgs and Jones (1991).

\section{Leaf nutrient status}

Leaf $\mathrm{N}, \mathrm{P}$ and $\mathrm{K}$ status of almond plants as influenced by rootstock and soil moisture is presented in Tables 7 to 9 .

\section{Nitrogen}

The data presented in Table 7 show that $\mathrm{N}$ content in scion leaves was not influenced by the rootstocks. However soil moisture levels exhibited a marked influence on the leaf $\mathrm{N}$ content. Highest leaf $\mathrm{N}$ content $(2.51 \%)$ was recorded in the plants irrigated at -0.5 bar which was markedly higher than the plants at other soil moisture tensions. This might be due to the fact that frequent irrigations at -0.5 bar could have increased the availability of $\mathrm{N}$ for its uptake. These results are inconformity with the findings of Baccino Giannetto and Garcia Petillo (1995). 
Table.1 Effect of rootstocks and moisture levels on plant volume $\left(\mathrm{m}^{3}\right)$ in almond cv. Non Pareil

\begin{tabular}{|l|l|l|l|l|l|}
\hline Rootstock & \multicolumn{5}{|c|}{ Moisture level (bar) } \\
\cline { 2 - 5 } & -0.5 & -2.5 & -5.0 & -10.0 & Mean \\
\hline $\begin{array}{l}\text { Bitter } \\
\text { almond }\end{array}$ & 1.16 & 0.78 & 0.55 & 0.30 & 0.70 \\
\hline Wild peach & 1.47 & 1.01 & 0.48 & 0.26 & 0.81 \\
\hline Mean & 1.32 & 0.90 & 0.52 & 0.28 & \\
\hline
\end{tabular}

$\mathrm{CD}_{(0.05)}$ Rootstock: 0.02 Moisture level: $0.03 \quad$ Rootstock x Moisture level: 0.07

Table.2 Effect of rootstocks and moisture levels on the total root length (m) in almond cv.

Non Pareil

\begin{tabular}{|l|l|l|l|l|l|}
\hline Rootstock & \multicolumn{5}{|c}{ Moisture level (bar) } \\
\cline { 2 - 6 } & -0.5 & -2.5 & -5.0 & -10.0 & Mean \\
\hline $\begin{array}{l}\text { Bitter } \\
\text { almond }\end{array}$ & 28.64 & 20.30 & 17.65 & 11.95 & 19.64 \\
\hline Wild peach & 17.00 & 12.79 & 10.48 & 8.17 & 12.11 \\
\hline Mean & 22.82 & 16.55 & 14.07 & 10.06 & \\
\hline
\end{tabular}

$\mathrm{CD}_{(0.05)}$ Rootstock: 0.69 Moisture level: $0.97 \quad$ Rootstock x Moisture level: 1.38

Table.3 Effect of rootstocks and moisture levels on the root weight ( $\mathrm{g}$ ) on dry weight basis in almond cv. Non Pareil

\begin{tabular}{|l|l|l|l|l|l|}
\hline Rootstock & \multicolumn{5}{|c|}{ Moisture level (bar) } \\
\cline { 2 - 6 } & -0.5 & -2.5 & -5.0 & -10.0 & Mean \\
\hline $\begin{array}{l}\text { Bitter } \\
\text { almond }\end{array}$ & 90.99 & 73.71 & 61.74 & 45.28 & 67.93 \\
\hline Wild peach & 84.51 & 47.05 & 37.31 & 30.23 & 49.78 \\
\hline Mean & 87.75 & 60.38 & 49.53 & 37.76 & \\
\hline
\end{tabular}

$\mathrm{CD}_{(0.05)}$ Rootstock: $1.61 \quad$ Moisture level: $2.28 \quad$ Rootstock x Moisture level: 3.22

Table.4 Effect of rootstocks and moisture levels on the biomass (dry weight of shoots and roots in $\mathrm{g}$ ) in almond cv. Non Pareil

\begin{tabular}{|l|l|l|l|l|l|}
\hline Rootstock & \multicolumn{5}{|c|}{ Moisture level (bar) } \\
\cline { 2 - 5 } & -0.5 & -2.5 & -5.0 & -10.0 & Mean \\
\hline $\begin{array}{l}\text { Bitter } \\
\text { almond }\end{array}$ & 390.1 & 296.2 & 245.5 & 193.9 & 281.4 \\
\hline Wild peach & 403.0 & 291.8 & 219.3 & 166.3 & 270.1 \\
\hline Mean & 396.6 & 294.0 & 232.4 & 180.1 & \\
\hline
\end{tabular}

$\mathrm{CD}_{(0.05)}$ Rootstock: $9.8 \quad$ Moisture level: $13.9 \quad$ Rootstock x Moisture level: 19.7 
Table.5 Effect of rootstocks and moisture levels on the rate of photosynthesis $\left(\mathrm{mol} / \mathrm{m}^{2} / \mathrm{S}\right)$ in almond cv. Non Pareil

\begin{tabular}{|c|c|c|c|c|c|}
\hline \multirow[t]{2}{*}{ Rootstock } & \multicolumn{5}{|c|}{ Moisture level (bar) } \\
\hline & -0.5 & -2.5 & -5.0 & -10.0 & Mean \\
\hline $\begin{array}{l}\text { Bitter } \\
\text { almond }\end{array}$ & 19.42 & 15.24 & 13.51 & 9.18 & 14.34 \\
\hline Wild peach & 19.82 & 16.60 & 12.97 & 8.51 & 14.48 \\
\hline Mean & 19.62 & 15.92 & 13.24 & 8.85 & \\
\hline
\end{tabular}

Table.6 Effect of rootstocks and moisture levels on the stomatal conductance $\left(\mathrm{mmol} / \mathrm{m}^{2} / \mathrm{S}\right)$ in almond cv. Non Pareil

\begin{tabular}{|l|l|l|l|l|l|}
\hline Rootstock & \multicolumn{5}{|c|}{ Moisture level (bar) } \\
\hline $\begin{array}{l}\text { Bitter } \\
\text { almond }\end{array}$ & -0.5 & -2.5 & -5.0 & -10.0 & Mean \\
\hline \begin{tabular}{l} 
Wild peach \\
\hline Mean
\end{tabular} & 0.73 & 0.62 & 0.37 & 0.11 & 0.48 \\
\hline \begin{tabular}{l}
$\mathrm{CD}_{(0.05)}$ Rootstock: 0.01 \\
\hline
\end{tabular} & Moisture level: 0.02 & 0.55 & 0.41 & 0.13 & 0.47 \\
\hline
\end{tabular}

Table.7 Effect of rootstocks and moisture levels on the leaf nitrogen content (\%) in almond cv. Non Pareil

\begin{tabular}{|l|l|l|l|l|l|}
\hline Rootstock & \multicolumn{5}{|c}{ Moisture level (bar) } \\
\hline $\begin{array}{l}\text { Bitter } \\
\text { almond }\end{array}$ & -0.5 & -2.5 & -5.0 & -10.0 & Mean \\
\hline Wild peach & 2.58 & 2.32 & 2.25 & 2.09 & 2.29 \\
\hline Mean & 2.51 & 2.39 & 2.19 & 2.06 & 2.29 \\
\hline
\end{tabular}

$\mathrm{CD}_{(0.05)}$ Rootstock: NS Moisture level: $0.02 \quad$ Rootstock x Moisture level: 0.03

Table.8 Effect of rootstocks and moisture levels on the leaf phosphorus content (\%) in almond cv. Non Pareil

\begin{tabular}{|l|l|l|l|l|l|}
\hline Rootstock & \multicolumn{5}{|c}{ Moisture level (bar) } \\
\cline { 2 - 6 } & -0.5 & -2.5 & -5.0 & -10.0 & Mean \\
\hline $\begin{array}{l}\text { Bitter } \\
\text { almond }\end{array}$ & 0.147 & 0.133 & 0.125 & 0.117 & 0.131 \\
\hline Wild peach & 0.153 & 0.139 & 0.122 & 0.114 & 0.132 \\
\hline Mean & 0.150 & 0.136 & 0.124 & 0.116 &
\end{tabular}

$\mathrm{CD}_{(0.05)}$ Rootstock: NS Moisture level: $0.002 \quad$ Rootstock x Moisture level: 0.003 
Table.9 Effect of rootstocks and moisture levels on the leaf potassium content (\%) in almond cv. Non Pareil

\begin{tabular}{|c|c|c|c|c|c|}
\hline \multirow[t]{2}{*}{ Rootstock } & \multicolumn{5}{|c|}{ Moisture level (bar) } \\
\hline & -0.5 & -2.5 & -5.0 & -10.0 & Mean \\
\hline $\begin{array}{l}\text { Bitter } \\
\text { almond }\end{array}$ & 1.15 & 1.10 & 1.07 & 1.04 & 1.09 \\
\hline Wild peach & 1.18 & 1.13 & 1.05 & 1.02 & 1.10 \\
\hline Mean & 1.17 & 1.12 & 1.06 & 1.03 & \\
\hline
\end{tabular}

However, the lowest leaf $\mathrm{N}$ content $(2.08 \%)$ was observed in plants irrigated at -10.0 bar. Interaction between rootstock and moisture level was significant. Plants on wild peach rootstock and irrigated at -0.5 bar tension had the highest leaf $\mathrm{N}$ content (2.53\%). The minimum $\mathrm{N}$ content $(2.06 \%)$ was observed in the plants grafted on wild peach rootstock and irrigated at -10.0 bar. Decreased leaf $\mathrm{N}$ content with increased soil moisture stress is in accordance with the findings of Davidyuk et al., (1972).

\section{Phosphorus}

Leaf $\mathrm{P}$ content in scion leaves was not influenced by the rootstock (Table 8). However soil moisture levels exhibited a marked influence on the leaf $\mathrm{P}$ content. Higher leaf $\mathrm{P}(0.150 \%)$ was recorded in the plants irrigated at -0.5 bar which was appreciably higher than those irrigated at other soil moisture levels. The higher leaf $\mathrm{P}$ content at lower soil moisture tensions might be due to the fact that frequent irrigations at 0.5 bar might have increased the uptake of $\mathrm{P}$. These results are in conformity with those Nawar and Ezz (1993). However, the lowest leaf $\mathrm{P}(0.116 \%)$ was observed in plants irrigated at -10.0 bar. Interaction between rootstock and moisture level significantly influenced the leaf content. Plants on wild peach rootstock, irrigated at $-0.5 \mathrm{bar}$, had the maximum leaf $\mathrm{P}$ content $(0.153 \%)$ while it was minimum $(0.114 \%)$ in the plants grafted on wild peach rootstock and irrigated at -10.0 bar. Similar findings were also made by Baccino Giannetto and Garcia Petillo (1995).

\section{Potassium}

It is obvious from the data presented in Table 9 that the foliar $\mathrm{K}$ content remained static in the plants raised on different rootstocks. However irrigation levels affected the uptake of leaf $\mathrm{K}$ content. $\mathrm{K}$ content $(1.17 \%)$ was markedly higher in the plants' irrigated at -0.5 bar than those irrigated at other levels. This might be due to the reason that frequent irrigations at -0.5 bar might have created conditions for the better uptake of $\mathrm{K}$ by the plants. Similar findings were also made by Baccino Giannetto and Garcia Petillo (1995). The minimum $\mathrm{K}$ content $(1.03 \%)$ was observed in the leaves of plants which were irrigated at -10.0 bar. The interaction between rootstock and moisture level also showed significant differences in the leaf $\mathrm{K}$ content. Plants on wild peach rootstock and irrigated at -0.5 bar contained the highest leaf $\mathrm{K}(1.18 \%)$, whereas the lowest $\mathrm{K}$ content $(1.02 \%)$ was observed in the plants on the same rootstock but irrigated at -10.0 bar. These findings are in agreement with those of Nawar and Ezz (1993) who also found decrease in leaf $\mathrm{K}$ under reduced soil moisture.

On the basis of above findings, it can be concluded that plants raised on bitter almond rootstock had less reduction in different 
parameters recorded at high soil moisture stresses (-5.0 and -10.0 bar) than the plants raised on wild peach rootstock thus under irrigated conditions, wild peach should be used as rootstock while as under rainfed conditions bitter almond should be used as rootstock for successful almond cultivation.

\section{References}

Abrisqueta, J.M., Hernansaez, A. and Franco, J.A. 1994. Root dynamics of young almond trees under different drip irrigation rates. J. Hort. Sci. 69(2): 237242

AO.AC. 1980. Official methods of Analysis of the Association of Official Analytical Chemists. AO.AC. Benjaminn Franklin Station, Washington. D.C.

Baccino Giannetto, G. and M. Garcia Petillo. 1995. Effects of two irrigation dates and two soil management systems on yield and qualilty of peach cv. 'Rey Del Monte'. Boletin de Investigacion Facultad de Agronomia Universitad de la Republica. 46: 24.

Chandel, J. S. and Chauhan, J.S. 1992. Drought resistance of Starking Delicious apple plants on different rootstocks. Indian J. Hort. 49(4):294299.

Chandel, J.S. and Chauhan, J.S. 1994. Effect of rootstocks and soil moisture stress on biomass, root growth and photosynthetic efficiency of apple. Prog. Hort. 26 (3-4): 136-140

Chapman, H.D. 1964. Suggested foliar sampling and handling techniques for determining the nutrient status of some field, horticultural and plantation crops. Indian J. Hort. 21: 97-119.

Cochran, G.C. and Cox, G.M. 1963. Experimental Designs. Asia Publishing House, Bombay. p.611.

Davidyuk, L.P., Koltsov, V.F. and Bezruchenko, O.E. 1972. The effect of drought on the synthesis of nitrogen compounds in peach fruits. Byull. Gosudar. Nikitskogo Bot. Sada. 3(19): 49-52.

Higgs, K. H. and Jones, H.G. 1991. Water relations and cropping of apple cultivars on dwarfing rootstock in response to imposed drought. J. Hort. Sci. 66(3): 367-379.

Jackson, M. L. 1967. Soil chemical analysis. Asia Publishing House, Bombay.

Kenworthy, A. L. 1964. Fruit, nut and plantation crops, deciduous and evergreen. A guide for collecting foliar samples for nutrient element analysis. Memo. Dept. Hortic. Michigan State University, Michigan.

Kester, D. W. and Grasselly, C. 1987. Almond rootstocks. In: Rootstocks for fruit crop (R. C. Rom and R. F. Carlson eds.). John Willey and Sons, New York, pp.265-293.

Koeing, R.A. and Johnson, R.C.R. 1942. Colorimetric determination of phosphorus in biological products. Indust. Engg. Chem. Anal. Ed. 14: 155164.

Kumar, S. 1987: Effect of rootstock and scion cultivars on foliar nutrient status in almonds. M.Sc. Thesis, Dr. Y.S. Parmar University of Horticulture and Forestry, Nauni, Solan, India.

Malik, R.S., Sharma, I.P. and Bhandari, A.R. 1994. Soil water relations and water application efficiency of trickle irrigation under fruit crops apricot. Indian J. Agric. Res., 28(4): 263-269.

Micke, W.C., Freeman, M.W., Beede, R.H., Kester, D.E., Yeager, J.T., Pelletreau, K.G. and. Conelle, J. H. 1996. Almond trees grown on peach rootstock initially more productive. California Agric. 50(4): 29-31.

Natali, S., Bignami, C. and Cammilli, C. 1996. Effects of different levels of water supply in gas exchange of early 
ripening peach trees. Acta Hortic. 374: $113-120$.

Nawar, A. and Ezz, T. 1993. Leaf and root mineral composition as well as nitrogen and phosphorus metabolism in apricot seedlings grown under different soil moisture levels. Alaxandria J. Hart. Res. 38(1):355-372.

Neilsen, G.H., Neilsen, D., Kappel, F. and Forge, T.A. 2014. Interaction of irrigation and soil management on sweet cherry productivity and fruit quality at different crop loads that stimulate those occurring by environmental extremes. HortScience. 49(2): 215-220.
Piper, C.S. 1966. Soil and plant analysis. Hans Publication, Bombay.

Senin, V.I., Rastorguev, A.B. and Vodyanitskii, V.I. 1989. The effect of irrigation on the root system of apple transplants in the nursery. Sadovodstvo - i - vinogradarstvo. 6: 31-34.

Syrbu, I. G., Stoyanov, G.L. and Pitushkam, S.G. 1983. Characteristics of photosynthesis in peach trees on different rootstocks. Sadov Vinovino Moldavii. 9: 50-51.

Westwood, M.N. 1993. Temperate Zone Pomology. W.H. Freeman and Co. San Francisco, USA.

\section{How to cite this article:}

Sharma, M.K. 2018. Influence of Rootstocks on Plant Volume, Root Growth, Biomass, Water Relations and Leaf Nutrient Status of Almond cv. Non Pareil under Different Soil Moisture Regimes. Int.J.Curr.Microbiol.App.Sci. 7(11): 1213-1222. doi: https://doi.org/10.20546/ijcmas.2018.711.141 